Article

\title{
From Christian Mission to Transnational Connections: Religious and Social Mobilisation among Roma in Finland
}

\author{
Raluca Bianca Roman \\ School of History, University of St Andrews, St Andrews, KY16 9BA, UK; E-Mail: rr44@st-andrews.ac.uk
}

Submitted: 14 January 2020 | Accepted: 10 March 2020 | Published: 4 June 2020

\begin{abstract}
Based on the analysis of archival material, and combined with ethnographic fieldwork conducted among the Finnish Kaale (the Finnish Romani population) since 2011, this article looks at the historical intertwining of Roma religious and social activism in Finland from the beginning of the 20th century. A focus is placed on the role of the Gypsy Mission (Mustalaislähetys), nowadays Romani Mission (Romano Missio), in shaping both historical and present-day Roma policy, activism and mobilisation within the country. Founded in 1906, and initially led by non-Roma Evangelicals, its impact has nevertheless moved beyond a strictly Roma-focused/non-Roma-led mission. While rarely mentioned, Kaale were active participants within the organisation, and some of the earliest Roma activists were shaped within its midst. Furthermore, Roma mobilisation in the country continues to have a religious undertone, particularly in the contemporary transnational humanitarian work conducted by Finnish Kaale missionaries among Roma communities in Eastern Europe. Tracing the legacy of present-day religious mobilisation among Roma in Finland, as well as Finnish Roma's active involvement in shaping Roma-projects elsewhere in Europe, is therefore crucial in revealing not only contrasts in how Roma activism may have manifested during the interwar period in Europe (from political to religious, from Roma-led to Roma-focused) but points to the present-day influence of Evangelical missions in shaping particular visions of the 'future' among Roma communities across Europe.
\end{abstract}

\section{Keywords}

Eastern Europe; Evangelical; Finland; religion; Roma

\section{Issue}

This article is part of the issue "Gypsy Policy and Roma Activism: From the Interwar Period to Current Policies and Challenges" edited by Elena Marushiakova (University of St Andrews, UK) and Vesselin Popov (University of St Andrews, UK).

(C) 2020 by the author; licensee Cogitatio (Lisbon, Portugal). This article is licensed under a Creative Commons Attribution 4.0 International License (CC BY).

\section{Interwar Roma Emancipation: The Finnish Puzzle?}

Whenever discussing processes of Roma civic emancipation during the interwar period, the countries of Central, South-Eastern and Eastern Europe are recurrently mentioned as key examples of the rise of ethnic consciousness among Roma, a rise which would often be combined with an expressed sense of their national belonging. The analysis of this specific regional context is undoubtedly crucial in our understanding of both past and present-day Roma activism, as these countries appear to have been at the centre of debates which continue to be relevant to contemporary Roma mobilisation in Europe. Moreover, this region appears to have been at the forefront of conversations concerning the 'naming' of Roma/Gypsy communities, the establishment of Roma/Gypsy organisations, schools and cultural institutions (for Romania, see Achim, 2007; Matei, 2010a, 2010b) as well as the focus on the development of Roma/Gypsy-focused national policies (for the Soviet Union, see Marushiakova \& Popov, 2017, in press). Indeed, one might argue that such shifts and movements have inspired later developments both in their own countries and beyond.

However, much less focus has been placed on countries which may be seen as lying at the 'periphery' of empires, or countries which do not fit the category of Central, South-Eastern and Eastern Europe. Among these, Finland constitutes a particularly striking example, as a nation which had historically been at the crossroads of state powers (such as the Swedish Empire and Russia) 
and, especially during the interwar period (1918-1939), striving for the construction of its own national identity, in the aftermath of its independence from Russia and the aftermath of a bloody Civil War.

Within this context, it is interesting to observe how processes of Roma mobilisation have been shaped at the beginning of the 20th century, and through to the beginning of the Second World War, in Finland. This is primarily so given the important role occupied by the first and arguably most active Roma organisation in the country, the Gypsy Mission (Mustalais/ähetys; presently Romani Mission, Romano Missio), founded in 1906. While at its inception the Gypsy Mission was by no means a classic type of Roma organisation (namely, it was not led by Roma), it nevertheless constitutes an important example of how an organisation has moved from a historical position of non-Roma leadership to one which, under a revised name and agenda, is presently led primarily by Roma and focuses its work on Roma in the country. Furthermore, while its initial aims were the 'reaching out' to the Roma community conducted from a primarily religious standpoint, it has since moved to a primarily social work focus. Finally, the Gypsy Mission, though non-Roma led, was the first organisation in the country to address issues of equal rights and equal opportunities for Roma living in Finland, alongside being among the first in the world to bring forth the topic of labelling as a means to address widespread prejudices against this community.

Within this backdrop, this article will analyse the manifestations of religious and social mobilisation among Roma in Finland which have taken place within the frameworks of the Gypsy Mission, with a focus placed primarily on the Finnish Kaale (Finnish Romani population). A key focus will be placed on the Gypsy Mission's initial aims and goals, the Roma members of the organisation, and the ways in which present-day religious mobilisation of Pentecostal Kaale in the country needs to be understood in the background of a historical focus on education, evangelisation and social work which have shaped 'Roma work' (Romanityö, or Roma missionary work) in Finland for over a century. This approach, and therefore the contribution of this article, is not only relevant but crucial in gaining a better understanding of the diversity of emancipatory actions which took place during the interwar period, therefore contributing not only to scholarly debates within the field of Romani studies concerning processes of Roma mobilisation and Roma activism but also highlighting the active role played by Roma themselves in the shaping of their own visions of the future.

Methodologically, the arguments in this article are based on two key sources of information. The first one comprises extensive ethnographic fieldwork conducted among the Kaale since 2011, consisting of participant observation, living with and among Kaale families in Southern Finland, in-depth interviews with Kaale Pentecostal believers, family histories and life histories, and participation in the transnational missionary projects conducted by Kaale missionaries in Central and Eastern European countries. These are all crucial in understanding the contemporary transnational character of their religious and social activism, which may (or may not) have its own political consequences. The second source of data informing the arguments of this article consists of archival materials gathered over the past two years. These comprise both the contents of the Gypsy's Mission main publication (namely, the newspaper Kiertolainen), and additional material collected from and with the aid of the Finnish Literature Society. The latter materials concern specifically the work of later activists among the Finnish Kaale (such as Ferdinand Nikkinen and his son, Reima Nikkinen), alongside that of key civic Roma organisations in the country (such as the Romanengo Staggos [Roma Association]), which came to act almost as a counterpoint to the Mission's aims: namely, moving away from the 'spiritual' dimension of the Gypsy Mission's work, to a more secular one focusing on social activism, non-religious education and improving the image and role of the Finnish Roma within mainstream Finnish society. The aim is thus to understand both the legacy of the Gypsy Mission's work among later activists in the country and the ways in which the focus and aim of missionary work currently taking place among the Finnish Kaale needs to be understood in a longer historical perspective: as shaped and as shaping particular imaginaries and visions of the future of Roma communities, within the language of faith and the discourse of Evangelisation.

Before proceeding to the analysis of the material, some terminological points should be made. Firstly, whenever using historical sources, and for accuracy purpose, I will maintain the terms used in the material presented and the cited sources: Roma, Gypsy or Kaale. However, whenever using contemporary experiences and in the analysis of the material, I will be using the term 'Roma,' with the exception of the discussion concerning present-day religious mobilisation, where the discussion will be on the 'Finnish Kaale,' a term my interlocutors used for themselves, and a term also found within the historical sources used for the purpose of this article. Secondly, it should also be noted that while the 'Roma community in Finland' has often been portrayed through an almost homogenising frame (i.e., often referred to as 'the' Finnish Roma), presently there are (and historically have been) several Roma/Gypsy groups inhabiting or moving through Finnish lands. These include, historically, temporary economic migrants from Russia or other Nordic European countries (cf. Tervonen, 2010, 2012a, 2012b) and, presently, Eastern European Roma migrants living in cities across the country (Roman, 2014; Tervonen \& Enache, 2017). In this article, however, the focus will be exclusively on the Finnish Kaale, whose presence in the country goes back to the early 16th century and the interchanging concepts used (Roma/Kaale or Gypsy) are grounded in either the ways in which the term was used in historical sources or the ways in which 
the people I have worked with referred to themselves. Nevertheless, it is important to stress that they are not (nor have been) one homogeneous community but, rather, have always found themselves in interaction with local majorities and other national Roma communities.

\section{A Backdrop to Roma Activism in Finland? The Inception of the Gypsy Mission and the Shaping of Social Work}

The Gypsy Mission is the first and oldest Finnish organisation to focus exclusively on the country's Roma population. It is interesting to note that while the Gypsy Mission was at its inception an eminently 'external' project (as in, run and led primarily by non-Roma), it has changed its approaches and policies several times, throughout different historical periods. An example of this is the movement from the 20th century primary focus on spiritual Evangelism to the more interventionist policies of the 1950s, and the collaboration with state institutions and incentives to 'civilise' the Roma. Another notable move was the gradual addition of more Kaale individuals as actual leaders of the organisation. As such, the first Roma managing director was Henry Hedman, appointed in 1996. Connectedly, the change of the name from the Gypsy Mission to Romani Mission occurred in the same year, in 1996 (Hedman, 2012, pp. 254-255). While there is no space to go into detail about these shifts, they mirror broader shifts occurring in the political discourse concerning Roma in the country, specifically in the 1990s, which argued for a larger participation of Roma in society and a recognition of their role as active members of society (for more, see Hedman, 2012). Yet, as will be argued throughout this article, Roma were always active and engaged members of the Gypsy Mission, even when not in leadership positions. As such, the acknowledgement of their voices, from the onset, needs to be taken into account when assessing the complex history of the Gypsy Mission.

Founded in 1906, the organisation's main aims were those of conducting a spiritual awakening among the Kaale in Finland, along with providing social and educational projects. Alongside these, the organisation also put an active emphasis on the process of sedentarisation and the role of children's education in the social integration of this community within mainstream society. The organisation thus aimed to address, in incipient forms, that which they identified as being both the spiritual and social 'needs' of the Roma community in Finland and began its work at the initiative of one person: Oskari Jalkio (1882-1952, born Storbacka, also known as Oskari Johnsson and sometimes publishing under the pseudonym Andreo Phaal, the latter term meaning 'brother' in the Romani language). In fact, Jalkio himself was an interesting character, who, alongside his wife
Helmi, is often attributed to being the inspiration behind many of the organisation's ventures. Born in 1882 in Teerijärvi, Eastern Finland, he was initially affiliated with the Finnish Free Church, an Evangelical Protestant movement particular to Finland and also affiliated with a revivalist, reformist group within the Free Church called Evangelical Friends. The latter was founded by a friend of Jalkio, Axel Alfred Skutnabb (Mäkinen, 2014, p. 44; Tervonen, 2012a, p. 125; Viita, 1967, p. 25). Grounded in his interest in Roma, Jalkio published several small materials concerning social structure and folklore, including a book of collected Roma songs, many of which had previously featured in the pages of the Mission's journal, Kiertolainen (Jalkio, 1939). Among other things, and beyond his interest in Roma, Jalkio was also a devout pacifist and a promoter of vegetarianism (Jalkio, 1925).

In terms of its inception, in 1905, a Tampere-based meeting, to which many Roma from across the country are said to have attended, led to the foundation of the idea to establish a 'Gypsy mission.' The aim was to focus on the 'spiritual and economical salvation of Roma' in the country and to welcome within its midst missionary workers from all denominations (Viita, 1967, p. 36). The central location of the organisation would initially be Tampere, with large tent meetings and off-spring charters being organised across the country: such as in Viipuri (present-day Vyborg), Oulu, Helsinki, Sortavala (where a children's home was also established), etc.

As mentioned above, the Mission also had its very own publication avenue: the newspaper Kiertolainen (translated as Traveller). Kiertolainen was published between 1907-1929, preceded in 1906 by a Christmas special issue Maailman kiertäjä ('World Traveller'). It is worth mentioning that, unlike the name of the organisation, which only changed its name in 1990, the name of the newspaper shifted several times. For example, from 1949, its name changed to Vaeltajankansa (The Wanderer People) and between 1956-1970 it was changed again to Kotitiellä (Home on the Road). Its current name, Romano Boodos (Roma News), was adopted in 1971.

The first leaders of the Mission were non-Kaale/nonRoma pastors and evangelists and the majority of active workers within the Mission (both as evangelists and as writers for their organisation's newspaper) were Jalkio's friends from the Evangelical Friends movement. The latter had begun a form of 'Roma-focused work' even before the official establishment of the Gypsy Mission. Nevertheless, as we will later see, though often seen as 'silent' members, the organisation could not have survived and developed as it did without the aid of key Roma figures within it (such as Sofia Schwartz, Antti Palm, Herman Korpp). ${ }^{1}$

One of the most interesting aspects of the Gypsy Mission, beyond its Evangelical incentives and faith-

\footnotetext{
${ }^{1}$ Beyond the focus on the Gypsy Mission, recent research in Finland has also highlighted the contribution of Roma to Finnish folklore (Mikkola \& Blomster, 2014), with others critically assessing the politics of collecting in Finland (Stark, 2016) and thus challenging previous misconceptions of Roma/Gypsies as being 'outside' of nation-building processes.
} 
based evangelism, was its focus placed on the topic of social work, in its various forms: educational, professional, and the support of those without homes or work. A clear example of this sort is the first Roma School (Romanikoulu) to be organised in the country, between 1905-1907, in Viipuri (presently Vyborg, in Russia). Not only was this a first in terms of its pupils but also in the fact that of its teacher was a Kaale woman under the name of Sofia Schwartz (1887-1932).

In fact, Sofia Schwartz (later, Santamo) was one of the first female teachers (Kaale or not) in early 20th century Finland. She was also a recurrent writer for the newspaper Kiertolainen and supported the Mission in many of its activities (cf. Schwartz, 1907). Born in Kuivaniemi (Northern Ostrobothnia), Schwartz graduated from elementary school in 1905, in Paltamo, where she eventually met Oskari Jalkio. It was Jalkio who would arrange her to become a teacher for Roma children in the newly proposed Viipuri Roma school. After the closing of the school, Sofia Schwartz would later be employed within the Sortavala children's home and was to become an advocate within the Gypsy Mission for the settlement of Roma in Finland, which was also a key aspect of the organisation's social interventions at the time (for more, see Rekola, 2010). She died in 1932, at the age of 45 , but continued to be mentioned as a key figure of the Gypsy Mission in the journal's publications.

The Roma school in Viipuri, while having a limited run of two years, was notable in several respects. It brought forth the issue of education as a key feature and theme within the Gypsy Mission and made it as its aim the schooling of Roma children from across the country. It also gained the support of local authorities. Nevertheless, the school was a difficult project to keep alive and soon subsided under other activities of the Mission. In this respect, worth mentioning is also the first Romani course, which was organised in Seinajöki (in Central-Western Finland) in 1906 as well as the first Roma children's home, which was organised in Sortavala between 1910-1918. The latter's activities died down at the beginning of the First World War, but the Mission's children's homes continued to be a focus of their activities throughout its existence. For instance, Romani Mission (the re-structured Gypsy Mission) still has under its leadership two children's homes. While the postSecond World War period represented a somewhat dark period in the organisation's history, specifically in the 1950s (see Grönfors, 2012; Grönfors \& Viljanen, 2009; Tanner \& Lind, 2009), when the Gypsy Mission became affiliated to the state's incentive to make Roma into 'better' Finnish citizens, taking Roma children away from their families to educate them within the 'proper Finnish moral values' (see Friman-Korpela, 2014; Pulma, 2006; Stenroos, n.d.), the focus on children remains a key point in the organisation's history.

In many ways, the Gypsy Mission thus clearly aimed to combine spiritual work (such as tent and religious meetings organised across the country), with a social di- mension shaped within their social work. Suffice to say that such activities were not always uncontroversial, particularly after the Second World War, when the Mission became affiliated with state policies aiming to address the 'Gypsy question' in the country, at times by forcibly removing children from their families. At the same time, many of the early incentives could not have been successful or long-lasting without the aid of Kaale workers within its midst. While most of the members of the central board, at least at the beginning of the 20th century, were non-Roma, Kaale did feature as key members: both within its activities (such as speakers at local meetings) and as writers/figures within the Mission's newsletter articles.

Furthermore, while most of the preachers may have been non-Roma, there were notable exceptions, such as Antti Palm and Herman Korpp, who acted as speakers at various religious meetings, or Kr. Fr. Lindström, who acted as speaker and evangeliser among Roma in different localities, and continued to be a key figure within the pages of Kiertolainen even after the interwar period (see Lindström, 1913). In addition to this, an interesting development occurred within one local branch of the Gypsy Mission's organisational board, in Viipuri. This particular charter of the organisation seems to have had, in 1907, a membership made up of a majority of Roma (see also Tervonen, 2012a, p. 128). This situation did not last for long, as the Roma membership gradually decreased, due both to decreasing financial resources coming from the central organisation and potential conflicts of interest. As Tervonen has argued, the reasons, while unclear, may also lie behind the fact that Jalkio seemed to promote a religion-first approach to the Mission's work, as compared to the Viipuri charter's members' interest in improving first the social situation of Roma and later bringing in the spiritual dimension (Tervonen, 2012a, p. 128). Another possible element fuelling disagreements within this branch may have been the charter's clear desire to have a higher level of autonomy and independence, which may not have been received with open arms by the centre.

What is clear, however, is that Kaale employees and workers within the Gypsy Mission facilitated not only the reach of the organisation but also, to some extent, its initial success. The notion of education was especially emphasised, be it in the organisation of schools and language courses or in the setting up of orphanages (for some articles depicting Kaale member's own voices and experiences as presented within the pages of the newspaper Kiertolainen, see Isberg, 1913; Lindström, 1913; F. Nikkinen, 1913; Schwartz, 1907). Furthermore, the focus on children's education and upbringing was recurrently on the cards of the Gypsy Mission and, later, of the reconfigured Romani Mission (see 'Mustalaislähetyksen r.y. säännöt', 1927). As can be seen from the presentday missionary activities of Pentecostal Finnish Kaale conducting work among Roma communities in Central, South-Eastern and Eastern Europe countries, education 
and the emphasis placed on children's upbringing into a Christian worldview continues to be at the centre of activities organised with a humanitarian aim. While this cannot be seen as a direct consequence of the Gypsy Mission's work, the continuities (and distinctiveness) of present-day religious humanitarianism need to be understood also by taking into account its historical configuration.

\section{Naming: On Labels and Labelling}

Over the past decades, increasing awareness of the power of labelling seems to have emerged, with Roma activists recurrently arguing for a terminological shift (from 'Gypsy' to 'Roma'), in diverse national contexts. While this may appear to be a post-socialist phenomenon, in reality, the topic of shifting terminologies has been predominant since as early as the interwar period (for Romania, see Matei, 2012). Yet, as will be evident from this section, this topic may have emerged much earlier, at the beginning of the 20th century.

In fact, one of the most interesting aspects within the aims and goals of the Gypsy Mission, as evidenced in an article published in the first issue of Kiertolainen, was Jalkio's pursuit for the change of terminology when referring to Roma in Finland (Jalkio, 1907, p. 5). Below is a translated segment of the above-mentioned manifesto for a terminological shift:

Kiertolainen's aim is to avoid the name 'mustalainen' ${ }^{2}$ as far as possible. Roma people often say: "It hurts like cutting with a knife when you hear the name mustalainen." So let us avoid that hated name. Let us use instead the name Romani (not romaani). Roma themselves use that name. We can use this name because it is very old and its meaning is so beautiful. Its origin is in the Sanskrit language 'dom' and in the Roma language, the word 'rom' means 'imies' = man (ihminen). We must still keep the name of our organisation 'Mustalaislähetys,' for various reasons.

In fact, through this, Jalkio, a non-Roma, may have been the first within the country (and, perhaps, in the world) to have pleaded for the terminological shift when referring to Roma. It is not made clear what or who had first planted this idea in Jalkio's mind, but the journal does indeed continue to use the term 'romani' throughout, with some exceptions (when translating poems or referring to a shift in lifestyle choices). Roma writers within the journal also used this particular terminology and, later, some mainstream media would also incorporate this format, whenever referring to the Gypsy Mission's activities. In addition to the term 'Romani,' the term 'Kaale' was also used, grounded once again in Jalkio's initial argumentation:
Besides the name 'romani' we can also use the name 'kaalo' (black, mustalainen). ${ }^{3}$ 'Romani' is the clean, unstained name inherited from forefathers and is an ancient name, but 'kaalo' ( $p l$. kaale, kaaleita) is the stained name, which describes the appearance or state of being of Roma people. It means the same as 'mustalainen,' but the difference is that hearing the word 'kaalo' does not hurt Roma as much as hearing the word 'mustalainen.' So if we want to find a corresponding name for 'mustalainen,' let us use the word 'kaalo,' otherwise let us use the word 'romani.'

While the Mission continued to keep the word 'Gypsy' in its title, the journal nevertheless began a shift in terms of the use of labels and influenced the subsequent usage of both terms. Through this, Gypsy Mission was not only a precursor to present-day debates but may have begun the shift in the first place. Given that the other well-known attempts to shift the terminology are those in Romania (primarily in Roma-led newspaper publications of the 1930s), this first issue of Kiertolainen is a crucial manifestation of the long history of this debate.

\section{From the Silence of the Interwar to the Criticism of the Postwar: The Emergence of the Roma Civic Movement in Finland}

One of the striking elements concerning the process of interwar Roma mobilisation in Finland, especially when compared to Central, South-Eastern and Eastern Europe countries (such as Romania and Bulgaria), where the interwar was the period with the strongest Roma/Gypsy emancipation movements, is the apparent 'inactivity' or 'silence' concerning similar processes taking place in Finland at the time. This is particularly so, given the context in which a focus on Roma religious mobilisation seems to have been a strong feature in the country, long before 1918 .

This situation is grounded in the particular historical and social context of Finland between 1918-1938, a country battling in the aftermath of the Civil War, a period characterising Finland's transition from being a Grand Duchy of the Russian Empire to becoming an independent state. It was also a period within which Finland was struggling with an economic recession, country-wide starvation and a struggle to create a sense of unity in the follow up of a bloody internal conflict, which had torn the country apart and separated the 'reds' from the 'whites.' The latter two terms are often used to refer to the two sides of the 1918 Finnish Civil War: namely, the Finnish Socialist Worker's Republic, the 'reds,' who sought to establish a socialist Finnish Republic, and its opposition, the 'whites,' or the refugee government, whose aim was to stop the 'reds' from gaining political power.

\footnotetext{
2 The only English equivalent for 'mustalainen' would be Gypsy, though the meaning in Finnish points to the colour of the skin, and would literally be translated as 'dark-skinned' or 'black-skinned.'

3 'Kaalo,' like 'mustalainen' would also mean 'black,' but it is a translation from Romani language, rather than Finnish.
} 
For this reason, it is crucial to understand the manifestations of Roma emancipation (or, in this case, mobilisation) in its broader context, by focusing specifically on elements which may have shaped it. Furthermore, contributing to this may have been the fact that in 1931, Oskari Jalkio, had moved with his family to Haiti, to conduct missionary work (Tervonen, 2012a, p. 138; Viita, 1967, p. 118). During this time, the activities of the Mission vastly decreased. Some 'Roma Days' (Romanipäivät, or Roma celebration days) continued to be held, the best known being the one in Keuuru, but the number of publications of the Gypsy Mission and the number of events greatly diminished until after the Second World War. Finally, the post-war context became known as one of the darkest in the history of the organisation, when many of the activities of the Mission became more clearly tied with state incentives to 'civilise' Roma in Finland and transform them into 'acceptable' Finnish citizens (see, for instance, Friman-Korpela, 2014; Pulma, 2006).

In fact, the Gypsy Mission was never without its critics but a counter-point movement came to be crystallised specifically after the end of the Second World War when previous members affiliated with the Mission became some of its most outspoken critics. A key example of this was Ferdinand Nikkinen, a well-known Roma activist in the post-war context and the founder of the first civic Roma organisation in the country, Romanengo Staggos. $\mathrm{He}$ is also known for the critical standpoint he had taken against the Gypsy Mission.

Yet, his activities had not always been completely detached from those of the Mission. Nikkinen had written a short article in the journal Kiertolainen as early as 1913, arguing for the settlement of Roma in Finland (an issue of concern also for the Gypsy Mission) and against the following of particular traditions (such as clothing), which he saw as hindering Roma's possibility of advancing within Finnish society. Below is a translation of some segments of this key article:

Forgive me, that I dare to tell my opinion of how we could rise to the level of the civilized people. I do not know why our forefathers had to wander along the village roads. Roma of our time have inherited wandering from their parents. In general, Roma are persistent to keep their traditions. Good followers of traditions! It sounds lovely, but we should not admire these traditions, because our fathers have left us many bad traditions. There are, naturally, also many good thingsfor instance, our own language and nationality. If we retain our parents' way of life, our children will suffer from a similar misery and be despised by other people. Because of our bad habits, other nations despise us. This curse is a big burden on our shoulders. To remove this curse, we must leave aside our forefathers' inheritance-give up wandering, deceiving people in the selling of horses and in future-telling also. Let us ask for God's power that we could leave our bad habits and learn good habits instead. We ought to leave wandering and live in one place. We ought to leave begging and start to work, to leave deceiving and to be honest. We ought to leave superstition and believe in God. As we believe in God, we'll win everything good....Our and our children's happiness depends on us. Let us not waste our time with vanity. I have heard people say: 'We have tried to teach Roma to know God but they do not care.' Let us take Jesus to our hearts. He also gives us civilization. I have heard that many Roma children have forsaken a good offer. People have promised to pay for their education, but they have refused. If somebody offered this possibility to us, we would have accepted it with joy. We, who are a part of Roma youth, let us look at life with greater hopes. Let us not be content with misery. Let us strive for a better life. Let us throw away that which bind us to misery. Homelessness is the greatest curse in the world. A home-even a small one, can protect us from the storms of the world. For what lives a person, who does not know, where to sleep the following night? A wanderer does not know how lovely it is to work for a good life. (F. Nikkinen, 1913, p. 15)

While much of Nikkinen's focus in this article seemed to be aligned with the aims of the Mission-especially the topics of children's education and that of sedentarisation-(for similar concerns in other countries, see Marushiakova \& Popov, in press), two editorial notes highlighted already then a potential emerging conflict. In fact the two notes seemed to disagree with some key points that Nikkinen put forth. Below is a translation for the two notes:

Editor says: We disagree as to dresses and colours. They are a nice variation in our stiff fashion. It is not necessary to follow the fashion madness of our time.

The morality nowadays is worse than that of Roma people. We do not advise Roma youth to admire it. Let us follow Christ's morality. (F. Nikkinen, 1913, p. 15)

It is unclear why or how Nikkinen's views shifted towards an opposition of the Mission itself but it is certain that, after the Second World War, he became an outspoken critic of the organisation, its projects and its approach. Interestingly, in addition to this, and despite his references to God in the above-mentioned article, as well as the emphasis placed on the role of spiritual awakening and faith in the potential uplifting of Roma in the country, Nikkinen became an outspoken atheist. It remains, however, unclear how the two elements are connected. In fact, neither his son, Reima Nikkinen (who, in 1967, would go on to establish the Finnish Gypsy Association), nor others who had known him could elaborate on the reasons for the shift, other than Nikkinen's increased interest in reading mainstream literature, a manifested desire to help the Roma community in the country out- 
side of a religious discourse and a general curiosity for the world (R. Nikkinen, 2000, 2012). Furthermore, at the same time as Nikkinen moved away from the Gypsy Mission, he also became a critic of the lack of Roma voices within it (specifically the lack of Roma as board members) and, in 1946, he sent a letter to the Ministry of Interior, in which he collected 364 signatures from Roma men, asking the state for a more active involvement of Roma in matters that pertained to their own community (see Pulma, 2006, p. 166; see also Friman-Korpela, 2014; Stenroos, n.d.). While this letter did not lead to many changes at the time, in 1953 Nikkinen did successfully set up Romanengo Staggos, which later influenced the wider Roma civic movement in the country (cf. Friman-Korpela, 2014). Thus, though Romanengo Staggos was short-lived, it was nevertheless the precursor to a longer-lasting civic organisation, the Finnish Gypsy Association, founded in 1967, which continues to be active until present-day, under the name of the Finnish Roma Association. The latter constitutes a notable and important present-day Roma organisation in the country, making their contributions also within the field of policy work and policy implementation in matters pertaining the Finnish Roma community (for more, see Stenroos, n.d.).

In other words, the shape and discourse of presentday civic activism among Roma in Finland was, and continues to be, in connection (even when in contrast) to that of the religious organisation that shaped it: Gypsy Mission and, presently, Romani Mission. This is especially clear when looking at Nikkinen's move from a supporter of the Gypsy Mission, to one of its most fervent critics, as well as his continued efforts to work in support of the Finnish Roma community, outside of the Mission's activities. At the same time, the Gypsy Mission seems to have provided both space and means for future Roma civic activists to become politically and socially active, even when in opposition to the Mission itself (for before 1918, see Tervonen, 2012a, p. 132). In other words, by providing not only space within its official publication, Kiertolainen, but actively encouraging Roma writers to submit their experiences and thoughts for broader dissemination, the Mission created space for the shaping of a Roma intellectual elite, some of which would later become its very own critics. As such, alongside Nikkinen, other critical voices would later come also in the shape of Roma artists, writers, musicians and social workers, who had previously been pupils in some of the Mission's former children's homes or who had previously had some form of affiliation with the Mission (cf. Grönfors, 2012; Grönfors \& Viljanen, 2009; Roman, 2018a; Tanner \& Lind, 2009). Through this, and in the context of a long-lasting critical re-assessments of its previous projects, the Gypsy Mission's influence on the shape of Roma mobilisation in the country cannot be denied, either in its attempts to combine a religious and a social dimension to their work or in their shaping of future critics of its activities.

\section{From Christian Mission to Transnational Humanitarianism: The Continuities and Discontinuities of Religious Work among Roma in Finland}

Throughout my fieldwork with Pentecostal Finnish Kaale, I have been made well-aware of the importance not only of figures such as Oskari Jalkio in the religious life of my interlocutors but also of the legacy of the Gypsy Misson's early work on the shape of present-day Kaale missionary movements. Furthermore, the Mission's current publication, Romano Boodos, is a regular presence in Kaale believers' homes and one of the most recurrent topics of conversation among Pentecostal Kaale is that of faith and missionary work. That is to say, Pentecostal Kaale are not only preoccupied with the state of their individual believer's lives but are actively involved in sharing that faith with others. This is done both nationally, within Finland, and transnationally, through the medium of Roma-focused religious humanitarian projects they organise in Eastern European countries.

In fact, among the Pentecostal Kaale missionaries I have worked with, at least three such missionary projects are active in Romania alone, two of which began in 1990, soon after the fall of the Communist Regime in the country (for more, see Roman, 2018b). These projects, often led by Finnish Kaale believers (at times jointly with non-Kaale Pentecostal members of their congregations), were conducted specifically among Roma communities abroad, rather than among impoverished communities more broadly. Oftentimes, this type of religious humanitarianism, grounded in the discourse of Pentecostal evangelism, was linked to a perceived need for social action within the countries that were being missionised, which were seen as needing development and social intervention. This was grounded in, on the one hand, the evangelical ethics of missionary work so common among Evangelical communities more broadly (see Elisha, 2011; Kwayu \& Stambach, 2013; Malkki, 2015) and, on the other hand, the stated necessities of reaching out to other Roma communities, in other countries. In a sense, this was a form of both 'missionary work,' 'social work,' and 'Roma work.'

Most importantly, in all the projects that I came across, the emphasis was unequivocally placed on the issue of 'development' and education of Roma children within missionised settlements. Likewise, the notion of children as 'the future' of Roma communities was a recurrent theme within all of these missionary projects (cf. Roman, 2018b, 2019). Moreover, while each project would have their specific focus, all of them argued for the necessity of ensuring that the missionised Roma communities attained an equal footing within their majority society and the access to the means for achieving that. In that sense, though shaped in the language of Evangelism, a discourse of modern-day emancipation lay grounded in the emphasis placed on education. For them, that access was seen as being granted by the upbringing of children, as a pathway to shaping a different life for their community. 
Some of the most common means of approaching and achieving these goals were also reminiscent of the early projects of the Gypsy Mission in Finland: such as setting up day-centres for children, food cantines, preschool facilities within the missionised areas, the training of local pastors, etc. Through this, present-day religious mobilisation among Roma in Finland attained not only a transnational dimension but re-approached the topic of children's future (and, more broadly, the future of the Roma community itself) through the discourse of economic and social development. Though in distinct ways, these were also pivotal in the initial stages of the Gypsy Mission.

Nevertheless, the present-day manifestations of Kaale missionary work attain new meanings and dimensions, having gone from a primarily Roma-focused/nonRoma led movement, which aimed at bringing up the social status of Roma in Finland, to a Roma-focused/Romaled transnational engagement, shaped in the language of modern-day developmentalism. While that which brings them together are the focus on social inclusion and economic development, the main actors engaging in the leadership of these projects are no longer nonRoma evangelists but, rather, Kaale missionaries from socalled 'developed' Western countries, conducting their work among impoverished Roma communities in Eastern Europe. Through this, the future of these projects and the role they will eventually play in shaping a form of transnational Roma identity among its protagonists provide interesting and fruitful grounds to understand the complexity and diversity of 'emancipation' and 'mobilisation' processes, from both a historical and a contemporary perspective.

For this reason, this article aimed to highlight the necessity for both a historical and national contextualisation of the shapes that Roma mobilisation(s) may take, wherein Finland provides an important additional example, especially when compared to Roma/Gypsy emancipation movements in other European countries (Marushiakova \& Popov, 2017, in press; Matei, 2010b). This, I believe, invites further reflection on the continuities and discontinuities between early emancipatory movements and present-day forms of Roma activism. Most importantly, it also highlights the active role Roma/Gypsies/Kaale have always played in the history of social mobilisations in their respective countries, as agents and protagonists of their own lives and as actively contributing to shaping the future of their communities.

\section{Acknowledgments}

I would like to thank the Academic Editors and the three anonymous reviewers for their careful reading of my text and their insightful comments. I would also like to thank Risto Blomster not only for commenting on the article but for aiding with the collection of some of the materials that shaped it, as well as Marko Stenroos for offering invaluable feedback on an earlier draft. I am indebted to Alex Archer, for helping with the proof-reading of the entire text. Finally, my gratitude goes to all the Finnish Kaale who I have worked with throughout my fieldwork and who have continued to support and guide me in different ways.

\section{Conflict of Interests}

The author declares no conflict of interests.

\section{References}

Achim, V. (2007). Gypsy research and Gypsy policy in Romania 1920-1950. In M. Zimmermann (Ed.), Zwischen Erziehung und Vernichtung: Zigeunerpolitik und Zigeunerforschung im Europa des 20. Jahrhunderts [Between education and annihilation: Gypsy policy and Gypsy research in 20th century Europe] (pp. 157-174). Stuttgart: Franz Steiner Verlag.

Elisha, O. (2011). Moral ambition: Mobilization and social outreach in Evangelical megachurches. Berkeley, CA, and Los Angeles, CA: University of California Press.

Friman-Korpela, S. (2014). Romanipolitiikasta romanien politiikkaan: Poliittisen asialistan ja toimijakonseption muutos 1900-luvun jälkipuoliskon Suomessa [From the Roma policy to the politics of the Roma: The change in the political agenda and political agency during the 1900s] (Doctoral dissertation). University of Jyväskylä, Jyväskylä, Finland.

Grönfors, J. (2012). Mustalaislähetyksen lastenkotitoiminta [Gypsy Mission's children's homes]. In P. Pulma (Ed.), Suomen Romanien Historia [Finnish Roma history] (pp. 241-249). Helsinki: Finnish Literature Society.

Grönfors, J., \& Viljanen, A. M. (2009). “Ai tää lastenkodin lapsi"-Selvitys 16 Mustalaislähetyksen lastenkodeissa 1960-80-luvuilla eläneen romanin sijoittumisesta romaniyhteisöön ja suomalaiseen yhteiskuntaan ["Here's a child of the orphanage"Report 16 on the Roma living in the Gypsy Mission orphanages between the 1960s-1980s and their position in the Roma community and the Finnish society]. Jyväskylä: Nevo Roma Ry.

Hedman, H. (2012). Mustalaislähetyksesta Romani Missionksi [From Gypsy Mission to Romani Mission]. In P. Pulma (Ed.), Suomen Romanien Historia [Finnish Roma history] (pp. 250-258). Helsinki: Finnish Literature Society.

Isberg, M. (1913). Romanitytön ajatelmia [A Roma girl's thoughts]. Kiertolainen, 7-9, pp. 13-14.

Jalkio, O. (1907). Wälttäkäämme nimeä "mustalainen" [Let us change the name "gypsy"]. Kietolainen, 0, p. 5.

Jalkio, O. (1925). Vegetarismin perusteita [The foundations of vegetarianism]. Oulu: Suomen Vegetaarinen Yhdistys.

Jalkio, O. (1939). Romanenge Giilja: Romanilauluja [Roma songs]. Jyväskylä: Nuorten Todistus. 
Kwayu, A. C., \& Stambach, A. (2013). Take the gift of my child and return something to me: On children, Chagga trust, and a new American Evangelical orphanage on Mount Kilimanjaro. Journal of Religion in Africa, 43(4), 379-395.

Lindström, K. F. (1913). Elämänkertani [My life's story]. Kiertolainen, (7-9), pp. 6-8.

Mäkinen, J. (2014). Elämää ja Valoa 50 vuotta: Romanien, hengellisen romanityön ja Elämä ja Valo-järjestön historiaa [Life and Light 50 years: Roma, spiritual Roma work and Life and Light's history]. Sastamala: Elämä ja Valo.

Malkki, L. (2015). The need to help: The domestic arts of international humanitarianism. Durham, NC, and London: Duke University Press.

Marushiakova, E., \& Popov, V. (2017). In search of a social contract: Roma in the 20th and 21st centuries. Anthropological Notebooks, 23(1), 9-25.

Marushiakova, E., \& Popov, V. (in press). Roma voices in history: A source book. Roma emancipation in Central, South-Eastern and Eastern Europe from 19th Century until the Second World War. Leiden: Brill.

Matei, P. (2010a). Raporturile dintre organizațiile țigăneşti interbelice şi Biserica Ortodoxă Română [The relations between interwar Gypsy organisations and the Romanian Orthodox Church]. In V. Ciobanu \& S. Radu (Eds.), Partide politice și minorități naționale din România în secolul XX [Political parties and national minorities in Romania in the 20th century] (Vol. V, pp. 159-173). Sibiu: Techno Media.

Matei, P. (2010b). Romii în perioada interbelică: Percepții naționaliste [Roma during the interwar period: Nationalist perceptions]. In L. Fosztó \& S. Toma (Eds.), Spectrum: Cercetări sociale despre Romi [Spectrum: Social research on Roma] (pp. 15-40). Cluj-Napoca: Editura Institutului pentru Studierea Problemelor Minorităților Naționale.

Matei, P. (2012). Romi sau țigani? Etnonimele, istoria unei neînțelegeri [Roma or Gypsies? Ethnonyms, the history of a misunderstanding]. In I. Horváth \& L. Nastasă (Eds.), Rom sau țigan: Dilemele unui etnonim în spațiul românesc [Roma or Gypsy: The dilemmas of an ethnonym in the Romanian space] (pp. 13-73). Cluj-Napoca: Editura Institutului pentru Studierea Problemelor Minorităților Naționale.

Mikkola, K., \& Blomster, R. (2014). Inclusion and exclusion of Roma in the category of Finnish folklore: The collections of the Finnish Literature Society from the 1800 s to the 2000s. Journal of Finnish Studies, 18(1), 11-45.

Mustalaislähetyksen r.y. säännöt [The rules of the Gypsy Mission]. (1927). Kiertolainen, 2, pp. 23-24.

Nikkinen, F. (1913). Romaninuorisolle [To Roma youth]. Kietolainen, 7-9, p. 15.

Nikkinen, R. (2000). Reima Nikkinen's interview 3.2.1999 (interviewer Raila Halmetoja) [Audio Recording]. RN. Finnish Literature Society, Helsinki.

Nikkinen, R. (2012). Reima Nikkinen's interview
22.8.2012 (interviewer Risto Blomster) [Audio Recording]. 69. Finnish Literature Society, Helsinki.

Pulma, P. (2006). Suljetut ovet: Pohjoismaiden romanipolitiikka 1500-luvulta EU-aikaan [Closed doors: Nordic countries' Roma policies from 1500 s to the EU-era]. Helsinki: Finnish Literature Society.

Rekola, T. (2010). Santamo, Sofia: Kansallisbiografia, verkkojulkaisu [Santamo, Sofia: National biographies, online]. Studia Biographica. Retrieved from https:// kansallisbiografia.fi/kansallisbiografia/henkilo/9328

Roman, R. B. (2014). Transnational migration and the issue of "ethnic" solidarity: Finnish Roma elite and Eastern European Roma migrants in Finland. Ethnicities, 14, 793-810.

Roman, R. B. (2018a). "Neither here, nor there": Belonging, ambiguity, and the struggle for recognition among "in-between" Finnish Kaale. Romani Studies, 28(2), 239-262.

Roman, R. B. (2018b). Roma mobility, beyond migration: Religious humanitarianism and transnational Roma missionary work as de-contructions of migration. Intersections: East European Journal of Society and Politics, 4(2), 37-56.

Roman, R. B. (2019, March 8). Religious humanitarianism and fateful orientations among Pentecostal Kaale. American Ethnologist. Retrieved from https://americanethnologist.org/features/ collections/orientations-to-the-future/religioushumanitarianism-and-fateful-orientations-amongpentecostal-kaale

Schwartz, S. (1907). Kertomus Inkerin-maan romaneista [A tale of Ingrian Roma]. Kiertolainen, 7, pp. 6-7.

Stark, E. (2016). The policy of folklore, the politics of collecting it: Majority folklore on the Roma in the early 20th century Finland. EthnoAnthropoZoom, 15, 151-175.

Stenroos, M. (n.d.). The Roma civil rights movement as a counter-weight for religious assimilation in Finland. RomArchive. Retrieved from https://www. romarchive.eu/en/roma-civil-rights-movement/ roma-civil-rights-movement-counter-weight-religiou

Tanner, R., \& Lind, T. (2009). Käheä-ääninen tyttö [Hoarse-voiced girl]. Helsinki: Kustannusosakeyhtiö Tammi.

Tervonen, M. (2010). "Gypsies," "Travelers" and "peasants": A study on ethnic boundary drawing in Finland and Sweden, c. 1860-1925 (Doctoral thesis). European University Institute, Florence, Italy.

Tervonen, M. (2012a). Kiertolaisia, silmatikkuja ja rajojen ylittajia: 1800-luvun lopulta toiseen maailmansotaan [Vagrants, picked on and boundary crossers: From the 1800 s to the end of the Second World War]. In P. Pulma (Ed.), Suomen Romanien Historia [Finnish Roma history] (pp. 84-143). Helsinki: Finnish Literature Society.

Tervonen, M. (2012b). Romanit ja suuri muutos [Roma and the big move]. In P. Pulma (Ed.), Suomen Romanien Historia [Finnish Roma history] (pp. 
166-181). Helsinki: Finnish Literature Society.

Tervonen, M., \& Enache, A. (2017). Coping with everyday bordering: Roma migrants and gatekeepers in Helsinki. Ethnic and Racial Studies, 40(7), 1114-1131.
Viita, A. (1967). Mustalaisväestön hyväksi: Mustalaislähetystyö Suomessa v. 1904-1966 [For the wellfare of the Gypsies: The Gypsy Mission in Finland between 1904-1966]. Helsinki: Kirjapaino Aa Oy.

\section{About the Author}

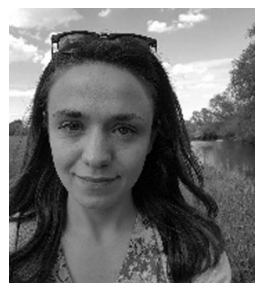

Raluca Bianca Roman is a Research Fellow in the 'Roma Interbellum' ERC project, within the School of History and an Associate Lecturer within the Department of Social Anthropology, University of St Andrews. Her PhD was an ethnographic study of religious mobilisation among the Finnish Kaale, with an emphasis on the relationship between religious change, social engagement and the development of Roma-led religious humanitarianism. Her current research centres on the processes of Roma civic emancipation in interwar Romania and Finland. 